\title{
Clinical Correlations of Serum Proinsulin-Like Material in Islet Cell Tumours***
}

\author{
R. N. Alsever, M. R. Stjernholm, K. E. Sussman, M. E. Mako and A. H. Rubenstein*** \\ Division of Endocrinology, Department of Medicine, University of Colorado School of Medicine and Veteran's Administration Hospital, \\ Denver, Colorado and University of Chicago School of Medicine, Chicago, Illinois, USA
}

Summary. To examine the possibility that the concentration of circulating proinsulin-like material (PLM) might be helpful in evaluating the therapeutic response of patients with islet cell tumours, serum levels of PLM in three patients with islet cell tumours were correlated with hypoglycaemic symptoms and plasma glucose concentrations before and after treatment. In two patients ranges of fasting PLM concentration were $0.21-0.29$ and $0.91-0.93 \mathrm{ng} / \mathrm{ml}$, respectively, before treatment. After surgical excision of their islet cell adenomas, PLM concentrations decreased to $0.06-0.09$ and $0.03-0.05 \mathrm{ng} / \mathrm{ml}$. Insulin concentrations were low preoperatively in both patients and were unchanged postoperatively. The resulting relief from hypoglycaemia was paralleled by a reduction of PLM, with no significant change in insulin. In a third patient, treatment with streptozotocin resulted in marked symptomatic improvement, a $65 \%$ reduction in PLM concentration, but no significant change in insulin levels. Relapse was associated with increasing frequency of hypoglycaemic symptoms and increasing PLM concentrations. These findings suggest that changes in the levels of serum PLM may prove to be a sensitive indicator of the response of islet cell tumours to therapy.

Key words: Hypoglycaemia, insulin, islet cell tumours, proinsulin-like material, streptozotocin.

\footnotetext{
* Supported by grants RR-51 from the General Clinical Research Centers. Program of the Division of Research Resources and Training Grant. 5 TO1 AM 05101, National Institutes of Health, Veterans Administration Endocrine Training Program TR-202 and USPH AM3941 and Bertha and Henry Brownstein Foundation

** Presented in part at the Fifty-Sixth Annual Meeting of the Endocrine Society, June 14, 1974, Atlanta, Georgia

*** Address reprint requests to Dr. A. Rubenstein, Box 435 University of Chicago, Illinois 60637
}

A high proportion of patients with islet cell tumours have elevated circulating concentrations of proinsulin-like material (PLM) [1-4]. Some of these patients may have relatively normal insulin levels [5]. Under these circumstances, we have considered the possibility that changes in the levels of endogenous PLM might be an important indicator of the response of the tumour to therapy. We have therefore correlated PLM concentrations with changes in plasma glucose and hypoglycaemic symptoms in three such patients with islet cell tumours before and after treatment.

\section{Material and Methods}

\section{Subjects}

Three patients with islet cell tumours were studied. Patient 1 (GW) is an 80 year old woman who developed hypoglycaemia after $3-10 \mathrm{~h}$ of fasting. At surgery, a single islet cell adenoma was found. Full details about this patient have been published [5]. Patient 2 (PL) is a 56 year old male who was repeatedly hypoglycaemic after 8-24 h of fasting. At surgery, two islet cell adenomas were removed. No evidence of parathyroid or pituitary disease was evident. Patient 3 (MC) is a 78 year old woman whose islet cell carcinoma was diagnosed at laparotomy. The tumour surrounded the celiac axis and was unresectable. No hepatic metastases were detected at surgery or by hepatic scintigraphy or arteriography. When initially seen, severe hypoglycaemia regularly occurred after 1-2 hrs of fasting. She was treated with streptozotocin (1.75 grams weekly) for 5 weeks. After the fifth dose she refused further treatment because of severe nausea and vomiting which occurred during the $36 \mathrm{~h}$ following each dose. No haematologic, hepatic or renal toxicity was detected during the treatment period. 
Table 1. Fasting plasma glucose levels and serum concentrations of total serum immunoreactive insulin (IRI), and insulin (I) and proinsulin-like material (PLM) after gel filtration in patient 1 (GW)

\begin{tabular}{|c|c|c|c|c|}
\hline $\begin{array}{l}\text { Plasma } \\
\text { glucose } \\
\mathrm{mg} / \mathrm{dl}\end{array}$ & $\begin{array}{l}\text { Total } \\
\text { IRI } \\
\mathrm{ng} / \mathrm{ml}\end{array}$ & $\begin{array}{l}\mathrm{I} \\
\mathrm{ng} / \mathrm{ml}\end{array}$ & $\begin{array}{l}\mathrm{PLM} \\
\mathrm{ng} / \mathrm{ml}\end{array}$ & $\%$ PLM \\
\hline \multicolumn{5}{|c|}{ Preoperative } \\
\hline 26 & 0.34 & 0.09 & 0.21 & 69.9 \\
\hline 23 & 0.44 & 0.16 & 0.29 & 63.1 \\
\hline 34 & 0.46 & 0.13 & 0.22 & 62.4 \\
\hline \multicolumn{5}{|c|}{ Postoperative } \\
\hline $190^{\mathrm{a}}$ & 0.25 & 0.12 & 0.06 & 35.4 \\
\hline $152^{\mathrm{b}}$ & 0.29 & 0.19 & 0.09 & 32.3 \\
\hline
\end{tabular}

a 1 month postoperative

b 6 months postoperative

\section{Sample Collection}

Three preoperative serum samples were obtained from patient 1 at the onset of hypoglycaemic symptoms and two from patient 2 after an overnight fast. Postoperative samples from both these patients were obtained after an overnight fast, one and six months after surgery. Simultaneously plasma glucose levels were determined on each sample. Serum samples from patient 3 were obtained before treatment, one week after the last injection of streptozotocin and thereafter when changes in the frequency of her symptoms were evident. Each specimen from this patient was obtained when she was hypoglycaemic (plasma glucose $30-38 \mathrm{mg} / \mathrm{dl}$ ). All samples were frozen in plastic vials at $-20^{\circ} \mathrm{C}$ until assayed.

\section{Analytical Methods}

Gel filtration of 1.0-2.0 ml of unextracted serum samples from patients 1 and 2 were carried out on $1 \times 50$ $\mathrm{cm}$ columns of Bio-Gel p-30 equilibrated in borate-albumin buffer, $\mathrm{pH}$ 8.0. Whole serum for total serum immunoreactive insulin (total IRI) as well as each gel filtration fraction were assayed in a double antibody insulin radioimmunoassay against a human insulin standard $[6,7]$. Unextracted serum samples from patient 3 were gel filtered on $1 \times 50 \mathrm{~cm}$ Sephadex G-50 (fine) columns according to the method of Gorden and Roth [8], except that elution was performed with a $3 \%$ albumin-barbital buffer, $\mathrm{pH}$ 8.6. Total IRI in whole serum, as well as the immunoreactive material in each gel filtration fraction, were measured in a double antibody insulin radioimmunoassay [9] against a porcine insulin standard. Porcine and human insulin standards did not differ by more than $5 \%$ in this assay.

The percent PLM represents that portion of the
Table 2. Fasting plasma glucose levels and serum concentrations of total serum immunoreactive insulin (IRI), and insulin (I) and proinsulin-like material (PLM) after gel filtration in patient 2 (PL)

\begin{tabular}{|c|c|c|c|c|}
\hline $\begin{array}{l}\text { Plasma } \\
\text { glucose } \\
\mathrm{mg} / \mathrm{dl}\end{array}$ & $\begin{array}{l}\text { Total } \\
\text { IRI } \\
\mathrm{ng} / \mathrm{ml}\end{array}$ & $\begin{array}{l}\mathrm{I} \\
\mathrm{ng} / \mathrm{ml}\end{array}$ & $\begin{array}{l}\text { PLM } \\
\mathrm{ng} / \mathrm{ml}\end{array}$ & $\%$ PML \\
\hline \multicolumn{5}{|c|}{ Preoperative } \\
\hline 75 & 1.11 & 0.12 & 0.91 & 87.8 \\
\hline 63 & 1.56 & 0.40 & 0.93 & 69.8 \\
\hline \multicolumn{5}{|c|}{ Postoperative } \\
\hline $119^{\mathrm{a}}$ & 0.28 & 0.29 & 0.05 & 14.4 \\
\hline $122^{\mathrm{b}}$ & 0.20 & 0.20 & 0.03 & 15.6 \\
\hline
\end{tabular}

a 1 month postoperative

b 6 months postoperative

insulin immunoreactivity present in the early eluting peak on gel filtration. The PLM concentration read from the insulin standard amounts to approximately $25-30 \%$ of the value that would be obtained by calculating the early eluting peak from a human proinsulin standard. Total IRI in unfiltered sera and insulin and PLM concentrations after gel filtration are expressed in nanograms per milliliter of serum. Normal fasting values (mean $\pm S$. D.) in our laboratory for total immunoreactive insulin (IRI) are $0.36 \pm 0.17$ $\mathrm{ng} / \mathrm{ml}(9.0 \pm 4.4 \mu \mathrm{U} / \mathrm{ml})$; for insulin $0.30 \pm 0.16 \mathrm{ng} / \mathrm{ml}$ $(7.6 \pm 3.9 \mu \mathrm{U} / \mathrm{ml})$; for PLM $0.16 \pm 0.09 \mathrm{ng} / \mathrm{ml}$ (read against a human insulin standard) and for percent proinsulin $12.8 \pm 4.6 \%$. Plasma glucose was measured by Technicon-Autoanalyzer.

\section{Results}

Preoperative and postoperative serum insulin and PLM concentrations, percent PLM and plasma glucose values for patients 1 and 2 are shown in Tables 1 and 2 , respectively. In patient 1 the range of fasting insulin was 0.09 to $0.16(2.3$ to $4.0 \mu \mathrm{U} / \mathrm{ml})$ when the plasma glucose was less than $34 \mathrm{mg} / \mathrm{dl}$. Postoperatively, the patient became asymptomatic, but there was no significant change in the insulin concentration. However, the 3-fold decline in the absolute concentration of PLM postoperatively resulted in a fall in the percentage of PLM from a mean value of 66.5 to $33.8 \%$.

The preoperative samples in patient 2 were obtained after an overnight fast and not when the patient was frankly hypoglycaemic. Postoperatively, after a similar overnight fast, total IRI fell 5-fold to 0.20 and $0.28 \mathrm{ng} / \mathrm{ml}(5.0$ and $7.0 \mu \mathrm{U} / \mathrm{ml})$, plasma glucose rose to 119 and $122 \mathrm{mg} / \mathrm{dl}$ and the patient became asymptomatic. On gel filtration, however, the insulin con- 


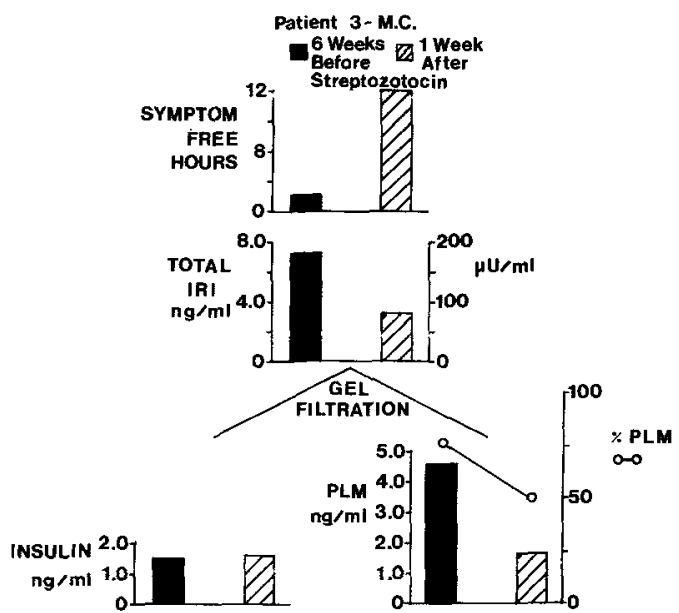

Fig. 1. Symptom-free hours (from the onset of fasting) and serum concentrations of insulin and PLM after gel filtration in patient 3 (MC) before (solid bars) and 1 week after (hatched bars) completion of streptozotocin treatment. Percent PLM (•-_- $)$ represents the contribution of PLM to the total immunoreactive insulin-like material from gel filtration

centrations were not different from the preoperative levels, but the PLM and percentage PLM were reduced to 0.03 and $0.05 \mathrm{ng} / \mathrm{ml}(0.75$ and $1.25 \mu \mathrm{U} / \mathrm{ml})$ and $14.4 \%$ and $15.6 \%$ respectively.

Total IRI and insulin, PLM and percentage PLM after gel filtration in patient 3 before and one week after completion of treatment with 8.75 grams of streptozotocin are correlated with the patient's symptoms in Figure 1. One week following the last injection of streptozotocin, there was a 6-fold increase in the length of time that fasting would result in hypoglycaemia. Accompanying this clinical change, total IRI decreased to $3.2 \mathrm{ng} / \mathrm{ml}(80 \mu \mathrm{U} / \mathrm{ml})$. Gel filtration of this sample showed that the insulin fraction was unchanged $[1.54 \mathrm{ng} / \mathrm{ml}(39.0 \mu \mathrm{U} / \mathrm{ml})]$ from the pretreatment value, while PLM had decreased to 1.63 $\mathrm{ng} / \mathrm{ml}(40.8 \mu \mathrm{U} / \mathrm{ml})$ and, as a consequence, the percent PLM had fallen to 51.

During the 19 weeks following treatment, the patient's symptoms returned to a level comparable to those in the pretreatment period. Figure 2 correlates the changes in clinical symptoms in patient 3 with the serum concentrations of insulin and PLM after gel filtration during this time period. As the length of time from the onset of fasting to the onset of hypoglycaemic symptoms decreased from 12 to $2 \mathrm{~h}$, the serum PLM increased. No consistent relation between symptoms and the insulin level was evident.

\section{Discussion}

Our data support the concept that the serum PLM concentration is a useful indicator of the activity of

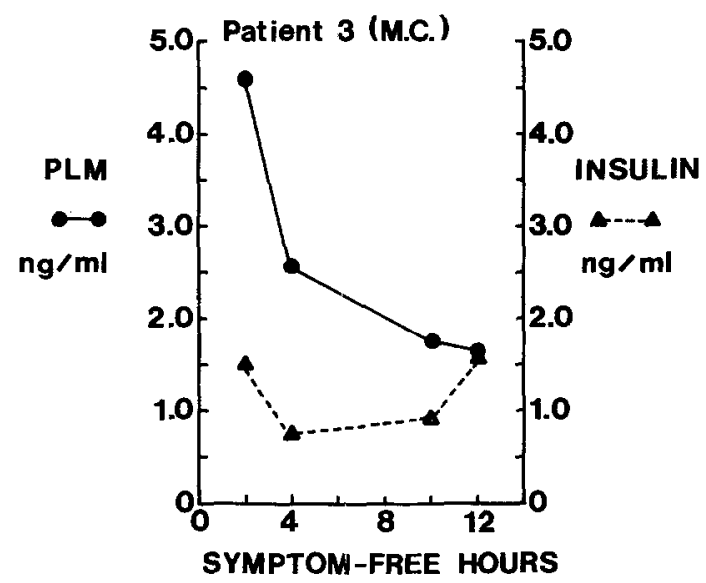

Fig. 2. Serum concentrations of PLM (--- ) and insulin ( (from the onset of fasting) during the 19 weeks following the last dose of streptozotocin in patient 3 (MC)

islet cell tumours in certain patients. The increases in blood glucose after operative excision of the tumours in two of our patients were associated with reductions in the serum PLM concentration, while insulin levels remained unchanged. In the third patient, the improvement in symptoms after streptozotocin treatment correlated with a decrease in PLM, but not with corresponding changes in insulin. Moreover, when relapse occurred, it was associated with a rise in PLM, but not insulin. A similar correlation between streptozotocin-induced remission and PLM was noted by Blackard et al. [10].

Our results indicate that the absolute concentrations of insulin and PLM may not be the only factors which determine the course of patients with islet cell tumours. Although the serum of patient 2 (Table 2) contained a 4-fold greater quantity of PLM (and almost twice as much insulin) than that of patient 1 (Table 1), hypoglycaemic cpisodes in this patient (No. 2) occurred less frequently. This result suggests the possibility that the character of the intermediates contained in the PLM fraction may differ in the two patients. Chance [11] and Yu and Kitabchi [12] have demonstrated that the hypoglycaemic activity of many of these two chain intermediates, which have single cleavages at the junction of the C-peptide and the $\mathrm{A}$ and $B$ chains, is substantially greater than that of the single chain parent precursor, proinsulin. These peptides, while not separated from proinsulin by gel filtration, may be identified using polyacrylamide disc gel electrophoresis [13]. Lazarus and co-workers pointed out the potential importance of these intermediates in determining the biologic activity of PLM in a patient 
with an islet cell carcinoma. The serum of this subject contained a high proportion of two chain intermediates, which were approximately $50 \%$ as active as insulin in the rat diaphragm bioassay [14]. We are presently perfecting methods to isolate these intermediates from serum so that we will be able to compare their immunological and biological activity with that of insulin and proinsulin.

We do not suggest a minor contribution of insulin to the production of hypoglycaemia. Although insulin concentrations were low in two of our patients, they may reflect an appropriate response to hypoglycaemia at the time of sample collection. Moreover, it is conceivable that insulin levels may have been elevated at other times if additional samples had been fractionated. The long half life of proinsulin [15] in comparison to insulin may result in raised PLM levels, while the insulin concentrations may have been only occasionally elevated. Gutman et al. [16] showed that slices of an islet cell adenoma ceased to secrete insulin when exposed to a low medium glucose concentration, but continued to secrete proinsulin-like material. If this same phenomenon occurs in vivo in other islet cell tumours, it is possible that insulin release may be appropriately inhibited by a falling circulating glucose concentration. The failure of PLM secretion to cease under these circumstances may indicate a potentially important role for this material in the production of hypoglycaemia by enhancing the effect of the falling serum insulin concentrations.

Acknowledgements. The authors wish to thank Michael A. Goldsmith, M. D., for providing the streptozotocin (lot number 73-207) for our patient. We express our appreciation to Paul Smith, M. D., for referral of G. W., Robert K. Johnson, M. D., for referral of P. L. and Willis Bennett, M. D., for referral of M. C. Finally, we are grateful for the technical assistance of Carolyn Hunka and secretarial help of Ellen J. Mohr and Vonne M. Kramsvogel.

\section{References}

1. Gutman, R. A., Lazarus, N. R., Penhos, J. C., Fajans, S., Recant, L.: Circulating proinsulin-like material in patients with functioning insulinomas. New Engl. J. Med. 284, 1003-1008 (1971)

2. Sherman, B. M., Pek, S., Fajans, S., Floyd, J. C., Conn, J. W.:
Plasma proinsulin in patients with functioning islet cell tumors. J. clin. Endocr. 35, 271-280 (1972)

3. Melani, F., Fyan, W. G., Rubenstein, A. H., Steiner, D. F.: Proinsulin secreted by a pancreatic beta cell adenoma. New Engl. J. Med. 283, 713-719 (1970)

4. Schein, P. S., DeLellis, C. R., Kahn, P., Gorden, P., Kraft, A. R.: Islet cell tumors: Current concepts and management. Ann. Int. Med. 79, 239-257 (1973)

5. Alsever, R. N., Roberts, J. P., Gerber, J. G., Mako, M. E., Rubenstein, A. H.: Insulinoma with low circulating insulin levels: The diagnostic value of proinsulin measurements. Ann. Int. Med. 82, 347-350 (1975)

6. Melani, F., Rubenstein, A. H., Steiner, D. F.: Human serum proinsulin. J. clin. Invest. 49, 497-507 (1970)

7. Starr, J. I., Rubenstein, A. H.: Insulin, proinsulin and C-peptide. In: Methods of hormone radioimmunoassay (eds. B. M. Jaffe, H. R. Behrman), pp. 289-315. New York: Academic Press 1974

8. Gorden, P., Roth, J.: Plasma insulin: Fluctuations in the "big" insulin component after insulin and other stimuli. J. clin. Invest. 48, 2225-2234 (1969)

9. Morgan, C. R., Lazarow, A.: Immunoassay of insulin: Two antibody system plasma insulin levels of normal, subdiabetic and diabetic rats. Diabetes 12, 115-126 (1963).

10. Blackard, W. G., Garcia, A. R., Brown, C. L.: Effect of streptozotocin on qualitative of plasma insulin in a patient with malignant islet cell tumor. J. clin. Endocr. 31, 215-219 (1970)

11. Chance, R. E.: Chemical, physical, biological and immunological studies on porcine proinsulin and related polypeptides. In: Proc. of the VII Congress of the International Diabetes Federation (eds. P. R. Rodriquez, J. Vallence-Owen), pp. 292-305. Amsterdam: Excerpta Medica 1971

12. Yu, S. S., Kitabchi, A. E.: Biological activity of proinsulin and related polypeptides in fat tissue. J. biol. Chem. 248, 3753-3761 (1973)

13. Gutman, R. A., Lazarus, N. R., Recant, L.: Biologically active circulating proinsulin-like materials from an islet-cell carcinoma patient. Diabetologia 8, 136-140 (1972)

14. Lazarus, N. R., Gutman, R. A., Penhos, J. C., Recent, L.: Electrophoretic characterization of circulating human proinsulin and insulin. Diabetologia 8, 131-135 (1972)

15. Starr, J. I., Rubenstein, A. H.: Metabolism of endogenous proinsulin and insulin in man. J. clin. Endocr. 38, 305-308 (1974)

16. Gutman, R. A., Fink, G., Shapiro, J. R., Selawry, H., Recant, L.: Proinsulin and insulin release with a human insulinoma and adjacent nonadenomatous pancreases. J. clin. Endocr. 36, 978-987 (1973)

Received: July 21, 1975, and in revised from: July 5, 1976

Dr. R. N. Alsever

Division of Endocrinology

Southern Colorado Clinic

2002 Lake Avenue

Pueblo, Colorado 81004

USA 